\title{
MITOLOGI PEREMPUAN SUNDA
}

\author{
Mythology of Sundanese Women
}

\author{
Oleh Agus Heryana \\ Balai Pelestaran Sejarah Dan Nilai Tradisional Bandung \\ Jl. Cinambo No. 136 Ujung Berung Bandung
}

Naskah Diterima: 26 Januari 2012

Naskah Disetujui: 24 Februari 2012

\begin{abstract}
Abstrak
Perempuan dalam dunia mitologi Sunda berada pada kedudukan yang terhormat. Kedudukan, harkat, dan martabatnya tidak berada di bawah kekuasaan laki-laki, bahkan dalam hal-hal tertentu menduduki tempat strategis dalam kerangka melahirkan seorang manusia yang berkualitas. Pengungkapan tokoh mitologi perempuan Sunda itu dilakukan melalui penggunaan metode deskripsi. Setiap tokoh diungkap dan hasil akhir yang diharapkan adalah memahami sosok perempuan Sunda dari segi spiritualitasnya. Penelusuran atas mitologi Sunda yang berkaitan dengan keperempuanan mengarahkan pada pengungkapan tipikal sosok perempuan Sunda yang terdapat pada tokoh-tokoh mitologinya. Tokoh mitologi itu di antaranya adalah Dayang Sumbi, Sunan Ambu, dan Sri Pohaci. Ketiga tokoh ini kemudian menjadi kekuatan spiritual, bukan saja untuk kaum perempuan Sunda sendiri, melainkan pula untuk orang Sunda secara keseluruhan dalam bertindak dan berperilaku.
\end{abstract}

Kata kunci: Perempuan Sunda, Dayang Sumbi, Sunan Ambu, Sri Pohaci, indung

\begin{abstract}
In Sundanese mythology women have a very respectable status. They are not subordinate to men. They even have much more strategic position then men are due to their capability of giving birth to persons of good quality. The author conducted descriptive method in order to reveal typical Sundanese women based on mythological characters. The author finds that three mythological Sundanese women (Dayang Sumbi, Sunan Ambu, and Sri Pohaci) have been spiritual strength for Sundanese women as well as for all Sundanese in their lives.
\end{abstract}

Keywords: Sundanese women, Dayang Sumbi, Sunan Ambu, Sri Pohaci, the mother

\section{A. PENDAHULUAN}

Sosok perempuan pada masyarakat moderen sering digambarkan dalam bentuk lahiriah. Adanya lomba kecantikan dengan berbagai bungkus atau label pada dasarnya untuk memberikan pencitraan terhadap sosok perempuan itu sendiri. Cantik, berkulit putih, berlaku lembut, berperasaan halus, lemah gemulai merupakan bentuk visual 
yang sering ditayangkan di media elektronik. Gambaran perempuan ideal dan nyaris tanpa cacat ini tenyata berhasil membuai kaum perempuan dengan membeli berbagai produk kecantikan. Berbagai perilaku "aneh" untuk membuat cantik dirinya, menurut pandangan lelaki, sering tampak ke permukaan. Barangkali ratusan bahkan jutaan rupiah dikeluarkan seorang perempuan untuk bisa tampil sebagai perempuan tercantik.

Tulisan ini bukanlah akan membahas kecantikan perempuan dengan segala pernak-perniknya, tetapi satu hal yang mengusik bahan pemikiran adalah perempuan pada akhirnya akan berlabuh pada satu kondisi yang mau tidak mau harus disandangnya sebagai ibu rumah tangga. Menjadi seorang ibu tidaklah semudah membalikkan tangan. Tak jarang seorang ibu harus mengabaikan kecantikan dan tubuh yang dirawatnya demi kebahagiaan putra-putrinya. Indung nu ngandung bapa nu ngayuga; munjung lain ka gunung muja lain ka sagara, tapi munjung kudu ka indung muja kudu ka bapa. (Ibu yang mengandung bapa penyebabnya; menyanjung bukan ke gunung, memuja bukan ke laut, tetapi menyanjung kepada ibu, memuja kepada bapak) adalah sebagian ungkapan yang masih dikenal orang Sunda dewasa ini. Di dalamnya tercermin penghormatan dan pemuliaan kepada kedua orang tua yang telah melahirkan dan merawat anakanaknya. Sosok Indung pada sanubari orang Sunda mempunyai makna lebih dalam. Pengertiannya tidak sekedar dan terbatas pada makna seorang perempuan yang melahirkan anak-anaknya. Lebih dari itu sosok indung telah menjadi simbol tertinggi dalam mitologi Sunda dan sekurangkurangnya mempunyai kedudukan terhormat dalam strata sosial masyarakatnya. Pertanyaannya adalah bagaimanakah perempuan (Sunda) menyiapkan diri untuk berperan sebagai indung atau ibu.

Dalam menjawab pertanyaan di atas tentunya berbagai jawaban akan dikemukakan orang sesuai dengan pengetahuan dan pemahamannya terhadap konsep yang dimilikinya. Seorang yang taat beribadah akan menjawab berdasarkan konsep agama- nya, demikian pula mereka yang senang dengan kehidupan materialis akan menjawab dengan keyakinannya. Lepas dari itu semua makalah ini akan memberi bahan pemikiran filosofis atas peran perempuan Sunda yang tercerminkan pada mitologinya

Mitologi bukanlah fakta sejarah atau benda budaya yang kasat mata, melainkan sebuah bahan renungan untuk dikaji kandungan maknanya. Mitologi sebagai bahan renungan secara tidak langsung menggambarkan tata cara berpikir masyarakat Sunda lama yang mengarah pada cara berpikir mitis, bahkan dianggap tak rasional. Namun ini tidaklah berarti cara berpikir seperti itu bersifat irasional (Cassirer,1977: 72). Dengan cara berpikir mitis ini masyarakat Sunda lama pada saat itu telah menemukan dan mengukuhkan nilai-nilai budaya yang tetap berharga bagi masyarakat Sunda sekarang, bahkan justru sangat mungkin dibutuhkan.

Kebudayaan berdasarkan perkembangan alur pemikiran menurut Peursen (1980) terbagi menjadi tiga katagori, yaitu: mitis, ontologis, dan fungsional. Dalam katagori mitis, manusia dikuasai oleh alam pikiran mitologis, terpesona oleh daya-daya gaib alam, penuh rahasia, dan meresponnya secara "primitif". Pada katagori ontologis, manusia mulai mempertanyakan hakikat "sesuatu". Mulailah hasrat manusia untuk membedakan diri dari alam gaib. Sedangkan pada katagori fungsional, manusia menggunakan pola atau cara berfikir, dengan melihat sesuatu melalui nilai praktis dan rasional.

Mitis dan religi merupakan dua kekuatan yang masing-masing memiliki ciri tersendiri, seperti mitos; bercirikan "tidak adanya sebab atau alasan". Sedangkan Thomas Aquino (dalam Hedy, 1999) menyatakan bahwa kebenaran religius bersifat suprarasional dan supranatural, namun tidak bisa disebut "irasional". Filsafat kebudayaan tidak melihat masalah religi itu sebagai sistem metafisis atau teologis, melainkan mempersoalkan bentuk imajinasi mitis dan bentuk pemikiran religius. Tak ada gejala alam dan gejala manusia yang tidak dapat diinterpretasikan secara mitis. Makna dan simbol di balik transendental mitis, secara 
bentuknya memiliki arti filosofi tersendiri, dan semua itu dapat diungkap melalui pendekatan filsafat. Mitos dalam pemahamannya dapat dibagi menjadi beberapa tipe, antara lain: mitos kosmogoni, mitos asalusul, mitos tentang dewa-dewa, makhlukmakhluk ilahi, dan sebagainya.

\section{B. HASIL DAN BAHASAN}

\section{Mitologi Perempuan Sunda}

Emeis (1971: 3) mengemukakan bahwa mite adalah cerita yang kuno-kuno dari zaman manusia masih merasa bersatu dengan alam dan kejadian gaib sekelilingnya. Mite biasanya melukiskan kelahiran bangsa, pertemuan orang tua-tua dengan dewa-dewa, roh, dan sebagainya. Karunia dan sengsara yang diperoleh, perjanjian dan juga larangan yang diadakan. Mite tidak berdasarkan pikiran logis, melainkan perasaan, pikiran mitis, yang tidak dimiliki manusia pada zaman modern ini.

William R. Bascom (dalam Dananjaja, 1986: 51) memperjelas pendapat Emeis bahwa mite adalah cerita yang dianggap benar-benar terjadi serta suci oleh yang punya cerita. Mite ditokohi oleh dewadewa atau makhluk setengah dewa, terjadinya di dunia lain atau di dunia yang bukan dunia seperti kita kenal sekarang, dan masa terjadinya sudah lama sekali. Mite sebagaimana dikemukakan oleh Hoykaas (1952: 117) ialah cerita dewa-dewi yang bersumberkan keagamaan dan merupakan kepercayaan asal-usul suatu bangsa atau keturunan, di samping mengandung unsur ajaib.

Berdasarkan pendapat beberapa tokoh sebagaimana dikemukakan sebelumnya dapat disimpulkan bahwa mite senantiasa berhubungan dengan sifat suci, gaib, dan sakti, dipercayai seakan-akan terjadi, tokoh pelakunya dihubungkan dengan dewa atau dewi, serta mempunyai latar belakang sejarah. Tokoh mite yang hidup dan sebagian masih sering menjadi tujuan persembahan upacara-upacara tertentu di masyarakat Sunda adalah Dayang Sumbi, Sunan Ambu, dan Nyi Sri Pohaci. Sosok masing-masing tokoh mite tersebut akan diuraikan di bawah ini.

\section{a. Dayang Sumbi: Perempuan Pertama (Orang) Sunda}

Sebuah cerita lisan yang telah melegenda di Tatar Sunda adalah Sasakala Gunung Tangkuban Parahu dengan tokoh utamanya Sangkuriang dan Dayang Sumbi. Legenda -- yang dalam istilah sastra Sunda disebut Sasakala - Sasakala Gunung Tangkuban Parahu sering disebut dengan judul lain, yaitu Legenda Sangkuriang Kabeurangan. Tampaknya Legenda Gunung Tangkuban Parahu kalah pamornya dengan judul legenda Sangkuriang (Kabeurangan). Padahal ditinjau dari segi ceritanya, alur cerita dan tokoh pemerannya sama, yaitu Sangkuriang dan Dayang Sumbi.

Beberapa penulis membedakan penulisan nama Sangkuriang antara Sangkuriang (satu kata) dan Sang Kuriang (dijadikan dua kata). Pembedaan penulisan ini berkaitan erat dengan pemaknaan tokoh itu sendiri. Ajip Rosidi (1985) menuliskan secara terpisah antara Sang dengan Kuriang hingga ditulis menjadi Sang Kuriang. Ajip Rosidi tidak mengemukakan alasan pemisahan, namun hemat penulis makna Sang Kuriang bertalian dengan nama Sang Guriang, sosok dewa di alam mitologi sebagaimana muncul dalam cerita pantun Mundinglaya Dikusumah' atau Sang Kuriang pecahan dari kata Sang Kuring, Sang Aku. Sebuah tafsiran ke arah filsafat eksistansialis (?); pencarian ego. Sedangkan Edi S. Ekadjati (2005) menulisnya dengan cara menyatukannya menjadi Sangkuriang. Dalam penulisan selanjutnya penulisan nama mengacu pada penyatuan antara Sang dan Kuriang, yaitu Sangkuriang. Sangkuriang adalah nama seseorang, nama diri yang tidak lebih seperti nama manusia biasa.

Tinjauan dari segi sastra, terutama pada sub penokohan menunjukkan hanya ada dua nama yang mendominasi seluruh cerita, yaitu Dayang Sumbi dan Sangkuriang. Dayang Sumbi seorang perempuan cantik jelita dan Sangkuriang seorang lakilaki tampan yang sakti mandraguna. Keduanya memiliki karakter yang berbeda, karakter perempuan dan karakter laki-laki. Atau tidak menutup kemungkinan kedua tokoh tersebut "dapat dijadikan" stereotype perempuan dan laki-laki Sunda pada masa 
itu. Ajip Rosidi (Rosidi, 1985: 25-26) memberikan tafsiran kepada dua tokoh sentral ini sebagai orang-orang yang mempunyai keyakinan pada pandangannya sendiri. Orang-orang yang kuat pendiriannya yang tidak mudah digoyahkan. Akibatnya adalah konflik yang terjadi merupakan risiko yang harus dibayar dalam mempertahankan keyakinannya.

Dayang Sumbi yang yakin bahwa laki-laki yang melamarnya itu anak kandungnya sendiri, berusaha dengan akalnya untuk menghindarkan pernikahan di antara mereka. Mula-mula dia mengajukan permintaan yang menurut ukuran manusia biasa mustahil akan dapat dipenuhi. Tapi ketika ternyata Sang Kuriang akan dapat memenuhi permintaannya yang luar biasa itu pada waktunya, maka dia pun mencari akal pula dengan membuat ayam jantan berkokok dan mengibarkan boeh rarang sehingga langit di sebelah timur tampak putih bercahaya. Kisah ini merupakan cermin tentang perbenturan dua orang pribadi yang masing-masing yakin akan kebenaran pendiriannya (Rosidi,1985: 25-26)

Lepas dari berbagai tafsiran yang dikemukakan oleh para penulis terdahulu atas cerita Sangkuriang Kabeurangan, kita melihat sosok ibu yang tengah diperankan oleh Dayang Sumbi. Dayang Sumbi, sebagai seorang ibu, merahasiakan "keaiban dirinya" yang bersuamikan seekor anjing, $\mathrm{Si}$ Tumang, dan berayah sang celeng Wayungyang. Kerahasiaan ini memang harus dibayar mahal, suaminya atau ayah Sangkuriang harus mati di tangan anaknya sendiri akibat ketidaktahuannya itu.

Sifat lain yang dimiliki Dayang Sumbi adalah tepat janji. Apa yang diucapkannya itulah yang dilakukannya. Ucapan yang akan menjadikan suami kepada siapa saja yang mengambil taropong, telah dibuktikannya dengan menerima Si Tumang, seekor anjing, sebagai suaminya. Ia berkeyakinan bahwa itu semua adalah kehendak Sang Dewa. Dalam hal ini tampaknya religius imani yang dimilikinya melahirkan sifat-sifat mulia. Dayang Sumbi adalah seorang manusia yang tidak terlepas dari keinginan-keinginan manusiawi; ketertarikan kepada seorang laki-laki tampan dan gagah adalah sesuatu yang wajar dan manusiawi. Oleh karena itulah tatkala bertemu dengan laki-laki yang menurut ukurannya sangat tampan dan gagah perkasa, hatinya pun terbuka untuk menerima cinta kasihnya. Itulah yang terjadi sebelum ia, Dayang Sumbi, mengetahui kekasihnya adalah putranya sendiri. Namun berbeda sikapnya ketika diketahui kekasihnya itu adalah putranya sendiri yang ia rindukan selama hidupnya. Sekuat tenaga ia berusaha menggagalkan lamaran anaknya, Sangkuriang, yang tidak mempercayai dirinya adalah ibu kandungnya. Keteguhan hati dan keluasan berpikir untuk jangka panjang telah menggagalkan rencana anaknya, Sangkuriang, yang bersikeras untuk menikahinya. Alhasil sosok ibu yang diperankan Dayang Sumbi adalah seorang ibu yang berpendirian teguh atas kebenaran yang diyakininya. Aib diri semaksimal mungkin harus dirahasiakan terutama kepada anggota keluarga sekalipun akan berakibat fatal. Selain itu menepati janji merupakan bentuk tanggung jawab seorang ibu atas semua yang diucapkannya.

\section{b. Sunan Ambu: Dewanya Perempuan (Orang) Sunda}

Perkataan Ambu tidaklah berarti perempuan, melainkan ibu; jadi menunjuk kepada sifat perempuan sebagai lambang kesuburan. Sedangkan perkataan Sunan ialah sebutan untuk orang yang dihormati, yang dijungjung di atas kepala. Jadi, Sunan Ambu secara harfiah berarti ibu (indung) yang hormati. Dihubungkan dengan penghormatan terhadap indung pare (ibu padi) yaitu padi yang dipanen lebih dahulu daripada yang lain dan diperlakukan sebagai sesuatu yang mulia, maka kita mendapat kesan adanya penghormatan atau pemujaan terhadap perempuan sebagai ibu (Rosidi, 1985: 44)

Keberadaan Sunan Ambu sebagai bagian dari mitologi orang Sunda dapat dirujuk pada carita pantun. Penelaahan atas beberapa cerita pantun seperti: Tujuh 
Ronggeng Kalasirna, Demung Kalagan, Mundinglaya Dikusumah, Lutung Kasarung dan Budak Manjor menunjukkan penyebutan nama Sunan Ambu. Memang tidak semuanya menyebutkan nama Sunan Ambu, tercatat dua cerita pantun saja, yaitu Lutung Kasarung dan Budak Manjor. Namun demikian perlu dicatat, bahwa tokoh-tokoh cerita pada cerita pantun yang lain menunjukkan dominasi perempuan sebagai tokoh ceritanya.

Sunan Ambu baik pada cerita Lutung Kasarung maupun Budak Manjor digambarkan sebagai perempuan yang berkedudukan tinggi di alam kahiangan, bahkan dalam Lutung Kasarung, Sunan Ambu membawahi para bujangga yang dijabat oleh 4 (empat) orang laki-laki, yaitu: Bujangga Tua, Bujangga Sakti, Bujangga Seda, dan Bujangga Tapa. Para bujangga inilah yang melaksanakan segala perintah Sunan Ambu untuk mengerjakan apa pun di Buana Pancatengah. Di samping para bujangga yang empat, ada lagi para pohaci, mereka itu wanita. Pohaci yang menjadi kepalanya adalah Wiru Mananggay. Para pohaci inilah yang membantu dan melaksanakan perintah Sunan Ambu yang bertalian dengan keperempuanan.

Cerita Lutung Kasarung oleh sebagian masyarakat Sunda, termasuk juru pantun sendiri, dianggap mempunyai daya magis yang tinggi; sehingga tidak sembarang orang membawakannya (menanggapnya). Sekurang-kurangnya dibutuhkan persyaratan-persyaratan yang khusus. Sursa (Suria Saputra) yang menulis buku Baduy dalam Naskah 13 tentang Bahasa (1950:5455), namun tidak diterbitkan; menyatakan bahwa :

"lakon pantun Baduy dan pantun luar Baduy banyak perbedaannya. Di luar Baduy ada 3 (tiga) lakon pantun yang terkenaldan dianggap keramat, ialah (1) Lutung Kasarung, (2) Ciung Wanara, (3) Mundinglaya Di Kusumah. Di Baduy, lakon Lutung Kasarung dan Ciung Wanara (Ciung Manarah) tak pernah dipantunkan, karena dianggap pusaka yang berhubungan dengan riwayat (baca: sejarah) dan perilmuan. Kedua lakon ini hanya diturunkan kepada murid-muridnya yang mengikuti pelajaran "pakem". Sedangkan lakon Mundinglaya Di Kusumah, di Baduy tidak ada.

Berkenaan dengan cerita patun Lutung Kasarung ada beberapa pristiwa yang menunjukkan tangan seorang ibu mengubah kehidupan putranya. Pertama, peristiwa Guru Minda berbuat ngalingling ngadeuleu maling; memandang ibunya dengan pandangan yang bukan semestinya. Kedua, adalah memberi bantuan kepada Guru Minda untuk menolong kekasih tercintanya, Purba Sari Ayu Wangi. Dan ketiga adalah mengajarkan cara bertani kepada Purba Sari Ayu Wangi.

Pada peristiwa pertama, Sunan Ambu bertindak bijaksana dan tegas saat mengetahui perbuatan anaknya, Guru Minda, yang tidak senonoh dan tidak pada tempatnya. Artinya, walaupun perbuatan anaknya dapat dimaklumi (dimaafkan) namun tidak berarti kesalahan itu dibiarkan tanpa sanksi apaapa. Sanksi yang tegas adalah "mengusir" anaknya secara halus dari Kahiyangan dengan alasan untuk mencari gadis pujaannya di Buana Panca Tengah.

Kesedihan Guru Minda menjadi lutung disikapi oleh Sunan Ambu dengan bijaksana. Ia mengatakan seperti yang disampaikan Bujangga Seda, ucapnya "Tong dianggo tatangisan kanyenyerian, lutung heulaanan wae, tong waka nembongkeun maneh". (Jangan ditangisi, biarlah lutung dahulu, jangan menampakkan diri ).

Selanjutnya, pengembaraan Guru Minda yang "menyamar" sebagai lutung telah membawanya kepada persoalan kesewenang-wenangan Purbararang atas Purbasari. Penindasan Purbararang kepada Purbasari dilakukan dengan berbagai cara. Intinya adalah memberikan perintah yang tidak mungkin dapat dilakukan oleh seorang perempuan lemah seperti Purbasari. Perintah-perintah itu adalah membendung Sungai Baranang Siang di lubuk Sipatahunan dalam tempo semalam; menangkap banteng lilin, menggarap huma, ladang dan sebagainya. Dalam pada itu Guru Minda yang pada saat itu menjadi lutung, bertindak sebagai dewa penolongnya. Namun pertolongan yang dilakukan Guru Minda bukanlah hasil jerih payahnya sendiri, melainkan 
hasil pekerjaan Sunan Ambu (ibunya) beserta para pembantu kepercayaannya (Bujangga dan Pohaci). Kasih ibu sepanjang masa kasih anak sepenggalan, demikianlah sebuah peribahasa yang menunjukkan kasih sayang seorang ibu tanpa batas; walaupun anaknya pernah berbuat dosa, tetapi kasih sayangnya melebihi kebencian dan kemarahannya. Guru Minda ditolong oleh ibunda tercinta, Sunan Ambu, sebagai wujud kecintaan seorang ibu kepada anaknya. Apa pun yang dimintanya, ibunya selalu berupaya untuk mengabulkannya, demi satu tujuan: kebahagiaan sang anak.

Purba Sari Ayu Wangi yang disiapkan untuk calon suami Guru Minda memperoleh kehormatan besar dari Sunan Ambu. Beliau dengan sengaja, tanpa menyuruh para pembantunya, mengajarkan kepada Purbasari bagaimana tatacara me-ngurus padi. Pada peristiwa ini tersimbul sebuah pelajaran bahwa seorang perempuan, apa pun status sosial dan jabatannya tak boleh lepas dari kodratnya; mengurus hal-hal yang berkaitan dengan keperempuanan, dalam hal ini adalah mengurus dapur (rumah tangga).

\section{c. Nyi Sri Pohaci: Dewi Padi}

"Tokoh" perempuan lain yang dianggap penting dalam mitologi Sunda adalah Dewi Sri. Nama diri Dewi Sri dalam khasanah kepercayaan Sunda memiliki nama lain. Nama yang dimaksud adalah Nyi Pohaci Sanghyang Sri, Nyi Dangdayang Tresnawati. Adapun kedudukan Dewi Sri dan Sunan Ambu memiliki tempat yang sama sebagaimana terlihat dalam mitologi orang Kanekes. Ada tiga tingkatan alam, menurut mitologi orang Kanekes seperti diungkapkan dalam cerita pantun. Ketiga tingkatan alam dimaksud adalah (1) Buana Nyungcung, tempat bersemayan Sang Hyang Keresa, yang letaknya paling atas, (2) Buana Panca Tengah, tempat manusia dan makhluk lainnya berdiam, dan yang paling bawah (3) Buana Larang, yaitu neraka. Antara Buana Nyungcung dan Buana Panca Tengah terdapat 18 lapisan alam yang tersusun dari atas ke bawah. Lapisan teratas bernama Bumi Suci Alam Padang atau menurut kropak 630 bernama Alam Kahiyangan atau
Mandala Hiyang. Lapisan alam tersebut merupakan tempat tinggal Nyi Pohaci Sanghyang Asri dan Sunan Ambu (Edi, 2005: 62-63) .

Sunan Ambu atas permintaan Guru Minda, ketika menolong Purba Sari dalam berbagai situasi cukup memerintahkan para pembantunya, yaitu Bujangga dan Pohaci. Misalnya, "menyulap" Aki Panyumpit yang tadinya melarat kemudian dalam sekejap mata menjadi berkecukupan, membendung Parakan Baranang Siang di Leuwi Sipatahunan, menangkap banteng lilin, membuka hutan untuk huma, ladang; hingga berlomba memasak yang berperan menolongnya adalah bujangga yang empat dan pohaci Wirumananggay. Namun tidaklah demikian manakala tiba pada pengurusan padi huma, Sunan Ambulah yang langsung menanganinya.

Masyarakat Sunda yang secara geografis dan demografis penduduk (masa silam) bermata pencaharian bertani, menempatkan sosok Dewi Sri pada tempat yang utama. Dalam berbagai aspek kehidupan, terutama hal-hal yang berhubungan dengan dunia pertanian, Dewi Sri menjadi pusat tujuan pemujaan. Berbagai upacara yang dilakukan masyarakat tani tidak lepas dari kepercayaan (baca: penghormatan atau pemujaan) kepada Sri Pohaci. Upacara Ngalaksa dan Seni Tarawangsa keduanya berasal dari daerah Sumedang, tepatnya di Kecamatan Rancakalong, merupakan bukti nyata atas semuanya itu. Upacara Ngalaksa merupakan ungkapan rasa syukur atas keberhasilan panen masyarakat setempat; dengan kata lain Upacara Ngalaksa merupakan upacara syukuran panen. Sementara seni Tarawangsa merupakan kelengkapan dari upacara Ngalaksa. Artinya di dalam Upacara Ngalaksa terdapat seni Tarawangsa atau seni Jentreng yang berfungsi sebagai "hiburan" kepada Dewi Sri.

Kembali pada nasihat Sunan Ambu di atas, kita melihat ada perlakuan luar biasa terhadap Sanghyang Sri. Dimulai dengan penyebutan nama tempat penyimpanan hasil panen (baca: leuit) dengan sebutan Pohaci Gedong Manik. Kata "Gedong" dalam bahasa Sunda berarti rumah besar yang mewah; sedangkan "manik" dapat diartikan intan 
atau berlian. Jadi, "Gedong Manik" adalah rumah besar yang mewah dan berisikan intan atau barang-barang berharga. Oleh karena itu mudah dimengerti apabila "penghuni" rumah tersebut diperlakukan sangat istimewa. Saat seseorang akan menuju Gedong Manik; ia harus berlaku sangat hormat dan sopan. Menahan nafas, mendahulukan kaki dan tangan kanan dalam setiap gerak langkah, dan berlaku sopan ketika mengambil padi. Sebutan mengambil padi pun harus dianggap ngagugahkeun, "membangunkan", sementara sebutan menumbuk padi harus diinterpetasikan sebagai meuseulan, pijatan kepada Sang Dewi yang baru bangun dari peraduan (Prawira Suganda: 1982: 150-174).

Penghormatan atau lebih tepat dikatakan pemujaan kepada Dewi Sri sebenarnya tidak dilakukan pada saat panen atau pascapanen, tetapi dimulai dari saat pengolahan tanah hingga pasca-panen. Adimihardja (1992: 145-155) memberikan gambaran secara utuh bagaimana masyarakat adat di kaki Gunung Halimun, Sukabumi, Jawa Barat melakukan aktivitas bertani, baik ladang maupun sawah. Pada aktivitas bertani tersebut terdapat mantera-mantera yang digunakan saat melakukan upacara pada setiap pergantian aktivitas. Misalnya, saat membuka ladang, seorang penggarap mengucapkan doa amit sebagai berikut:

\begin{tabular}{|l|l|}
\hline Pun ampun & Ampun kami \\
\hline ka luhur & ke atas \\
\hline ka sang rumuhun & $\begin{array}{l}\text { kepada sang } \\
\text { dewa yang } \\
\text { menguasai langit }\end{array}$ \\
\hline ka handap & ke bawah \\
\hline ka sang batara & $\begin{array}{l}\text { kepada sang } \\
\text { dewa yang } \\
\text { menguasai bumi }\end{array}$ \\
\hline ka para dewa-dewi & $\begin{array}{l}\text { kepada para } \\
\text { dewa-dewi } \\
\text { lainnya }\end{array}$ \\
\hline ka siluman & $\begin{array}{l}\text { kepada makhluk } \\
\text { halus yang jahat }\end{array}$ \\
\hline ka sileman & $\begin{array}{l}\text { kepada makhluk } \\
\text { halus yang baik }\end{array}$ \\
\hline $\begin{array}{l}\text { ka dewa kalakay } \\
\text { salambar }\end{array}$ & $\begin{array}{l}\text { kepada dewa } \\
\text { sekembar daun } \\
\text { kering }\end{array}$ \\
\hline anu nyicingan ieu bumi & yang berkuasa di \\
\hline
\end{tabular}

\begin{tabular}{|l|l|}
\hline $\begin{array}{l}\text { Adimihardja (1992: } \\
\text { 145) }\end{array}$ & alam jagat ini \\
\hline
\end{tabular}

Selanjutnya, penggarap melanjutkan kata-kata sebagai berikut:

\begin{tabular}{|l|l|}
\hline Ema & Ema \\
\hline Bapa, & Bapak, \\
\hline abdi neda widi & saya mohon izin \\
\hline bade muka ieu huma & akan membuka ladang \\
\hline ulah aya nu ganggu & $\begin{array}{l}\text { mohon tidak ada yang } \\
\text { mengganggu }\end{array}$ \\
\hline ngaguna sika & menggagalkannya, \\
\hline $\begin{array}{l}\text { berkah dua } \\
\text { salametna }\end{array}$ & berkah doa selamat \\
\hline kalawan & dan \\
\hline $\begin{array}{l}\text { rahayu sadayana } \\
\text { Adimihardja (1992: } \\
\text { 146) }\end{array}$ & rahayu semuanya \\
\hline
\end{tabular}

Taraf terpenting dalam menanam padi di ladang (huma) adalah ngaseuk. Ngaseuk kata kerja dari kata aseuk. Aseuk itu sendiri berarti tongkat yang ujungnya runcing dan berfungsi membuat lubang untuk benih padi. Pada saat ngaseuk inilah diadakan upacara yang cukup akbar dan meriah. Salah satu "doa" pada upacara Ngaseuk adalah sebagai berikut:

\begin{tabular}{|l|l|}
\hline Bul kukus & mengepul asap, \\
\hline doa rosul & doa untuk Rasul \\
\hline nya menyan & yaitu kemenyan \\
\hline pancerning iman & pusatnya iman \\
\hline $\begin{array}{l}\text { nitipkeun Sri Pohaci } \\
\text { purnama alam sajati }\end{array}$ & $\begin{array}{l}\text { kami titipkan Sri } \\
\text { Pohaci purnama alam } \\
\text { sejati }\end{array}$ \\
\hline ka sukmaning bumi & kepada sukma bumi \\
\hline ka rohaning bumi & kepada roh bumi, \\
\hline ka sukmaning geni & kepada sukma api \\
\hline ka rohaning bumi & kepada roh bumi \\
\hline kasukmaning geni & kepada sukma api \\
\hline ka rohaning geni & kepada roh api \\
\hline ka sukmaning angin & kepada sukma angin \\
\hline ka rohaning angin & kepada roh angin \\
\hline $\begin{array}{l}\text { Titip ka Prabu Susuk } \\
\text { Tunggal }\end{array}$ & $\begin{array}{l}\text { Titip kepada Prabu } \\
\text { Susuk Tunggal }\end{array}$ \\
\hline aku-akuan anak incu & $\begin{array}{l}\text { agar suka diaku anak } \\
\text { cucu }\end{array}$ \\
\hline putu Nabi Adam & cucu Nabi Adam \\
\hline $\begin{array}{l}\text { umat Nabi } \\
\text { Muhammad }\end{array}$ & $\begin{array}{l}\text { umat Nabi } \\
\text { Muhammad }\end{array}$ \\
\hline mihape bisi aya & kami menitipkannya \\
\hline anu ngaganggu & jangan sampai ada \\
\hline
\end{tabular}




\begin{tabular}{|l|l|}
\hline & yang mengganggu \\
\hline ngagunasika, & merusak \\
\hline bisi aya jin siluman & $\begin{array}{l}\text { kalau-kalau ada jin } \\
\text { siluman }\end{array}$ \\
\hline iblis, & iblis, \\
\hline $\begin{array}{l}\text { bisi aya } \text { nu } \\
\text { ngaganggu }\end{array}$ & $\begin{array}{l}\text { kalau ada yang } \\
\text { menganggu }\end{array}$ \\
\hline $\begin{array}{l}\text { rongrong } \\
\text { gogodongan }\end{array}$ & $\begin{array}{l}\text { segala macam } \\
\text { tumbuh-tumbuhan. }\end{array}$ \\
\hline $\begin{array}{l}\text { muga-muga } \\
\text { pangnyinglarkeun }\end{array}$ & $\begin{array}{l}\text { mudah-mudahan } \\
\text { dilindungi }\end{array}$ \\
\hline $\begin{array}{l}\text { aku-akuan anak incu } \\
\text { putu }\end{array}$ & aku-akuan anak incu \\
\hline Nabi Adam & Nabi Adam \\
\hline $\begin{array}{l}\text { umat Nabi } \\
\text { Muhammad }\end{array}$ & $\begin{array}{l}\text { umat Nabi } \\
\text { Muhammad }\end{array}$ \\
\hline nyuhunkeun lulusna & mohon keselamatan \\
\hline mulusna & keberhasilan, \\
\hline beresna palerena & agar hasilnya \\
\hline $\begin{array}{l}\text { sing aranekeh } \\
\text { alahbatan sereh }\end{array}$ & $\begin{array}{l}\text { berlipat ganda } \\
\text { (sadapuran sereh) }\end{array}$ \\
\hline sing arunukuh & agar berbuah lebat \\
\hline $\begin{array}{l}\text { ala batan dukuh } \\
\text { Adimihardja (1992: } \\
\text { 148) }\end{array}$ & \begin{tabular}{l} 
seperti buah dukuh \\
\hline
\end{tabular} \\
\hline
\end{tabular}

Tiba waktu panen dilakukan lagi upacara sebelumnya yang disebut Upacara Mipit atau bisasa disebut Nyalin. Pada upacara nyalin ini dibacakan doa (jangjawokan) seperti berikut:

\begin{tabular}{|l|l|}
\hline Bul ngukus & Asap mengepul \\
\hline doa rasul & $\begin{array}{l}\text { menyertai doa untuk } \\
\text { rasul }\end{array}$ \\
\hline $\begin{array}{l}\text { nya menyan } \\
\text { pancering iman, }\end{array}$ & $\begin{array}{l}\text { kemenyan sebagai } \\
\text { induk iman }\end{array}$ \\
\hline $\begin{array}{l}\text { hatur salam } \\
\text { panarima, }\end{array}$ & $\begin{array}{l}\text { menyampaikan } \\
\text { salam atas } \\
\text { perlindungannya }\end{array}$ \\
\hline $\begin{array}{l}\text { hatur sangu } \\
\text { pangabakti, }\end{array}$ & $\begin{array}{l}\text { menyampaikan nasi } \\
\text { sebagai tanda bakti, }\end{array}$ \\
\hline $\begin{array}{l}\text { jisim abdi bade } \\
\text { ngamitkeun ieu Sri }\end{array}$ & $\begin{array}{l}\text { kami akan } \\
\text { menyimpan Sri }\end{array}$ \\
\hline purnama alam sajati, & Pohaci \\
\hline $\begin{array}{l}\text { dumeh geud nepi kana } \\
\text { bukuning taun, }\end{array}$ & $\begin{array}{l}\text { karena sudah sampai } \\
\text { pada tahunnya }\end{array}$ \\
\hline $\begin{array}{l}\text { geus keuna } \\
\text { mangsaning bulan, }\end{array}$ & $\begin{array}{l}\text { karena sudah sampai } \\
\text { pada bulannya }\end{array}$ \\
\hline $\begin{array}{l}\text { nu ngarumpag } \\
\text { ngumbara di alam } \\
\text { dunya }\end{array}$ & $\begin{array}{l}\text { yang mengembara di } \\
\text { alam jagad ini, }\end{array}$ \\
\hline ayeuna geura marulih & sekarang silahkan \\
\hline
\end{tabular}

\begin{tabular}{|l|l|}
\hline $\begin{array}{l}\text { ka gedong Sri Ratna } \\
\text { Inten” }\end{array}$ & $\begin{array}{l}\text { masuk kembali ke } \\
\text { Gedung Sri Ratna } \\
\text { Inten }\end{array}$ \\
$\begin{array}{l}\text { Adimihardja (1992: } \\
\text { 150) }\end{array}$ & \\
\hline
\end{tabular}

\section{Indung: “Mata holang” Spiritualitas Ki Sunda}

"Mata holang" adalah idiom Sunda yang berarti sumber sekaligus pusat kehidupan atau ujung tombak dalam beraktivitas. Penyebutan indung bila disandingkan dengan ayah atau bapak akan lebih dominan penyebutan indung ketimbang ayah atau bapak; sekurang-kurangnya lebih awal atau lebih didahulukan. Misalnya, dalam bentuk sapaan sehari-hari kita lebih mendahulukan "ibu" daripada "bapak"; ibu bapak. Lebih dari itu kita mengenal sebutan "ibu pertiwi" dan "ibu kota" dan hingga laporan ini ditulis belum ada yang mengorbitkan atau sekurang-kurangnya mengusulkan "bapak pertiwi" dan "bapak kota" sebagai sandingan "ibu pertiwi" dan "ibu kota". Peribahasaperibahasa atau ungkapan-ungkapan tradisional yang digunakan pada tulisan ini pun lebih dominan penyebutan indung ketimbang bapak. Misalnya peribahasa Indung $n u$ ngandung bapa nu ngayuga; Indung tunggul rahayu bapa tangkal darajat; Munjung mah kudu ka indung muja mah kudu ka bapa; indung hukum bapa darigama; ngindung ka waktu mibapa ka zaman. Penyimpanan atau penyebutan kata indung sebelum bapa (bapak) bukanlah sebuah kebetulan atau sesuka hati pemakainya. Tetapi didasari oleh adanya pandangan-pandangan yang lebih menghargai indung (baca: perempuan) ketimbang laki-laki. Seolah-olah indung menjadi pusat aktivitas, pusat dunia. Oleh karenanya mudah dimengerti bila pada sebagian masyarakat tradisional indung menjadi pusat pemujaan atau puncak tertinggi "kekuasaan". Dalam sebuah keluarga pun kadang-kadang posisi indung ditempatkan pada "posisi" strategis ketika terjadi peristiwa yang menggoncangkan tatanan keluarganya. Misalnya, kesalahan yang diperbuat oleh seorang anak, seringkali permintaan maaf dimohonkan terlebih dahulu pada atau melalui ibu daripada ayah, seperti tercermin dalam ungkapan bahwa Indung 
mah gede hampura (Ibu selalu memberi maaf). Hal ini tidak saja memperlihatkan hubungan anak sangat dekat dengan ibunya, tetapi tampaknya juga meletakkan suatu status tersendiri bagi wanita dalam masyarakat Sunda (Judistria Garna dalam Ekadjati, 1984: 36)

Menghayati peran sebagai seorang indung bukanlah hal yang mudah. Perjuangan dan pengorbanan seorang indung begitu besar dalam mendedikasikan hidupnya bagi tumbuh dan berkembangnya generasi berkualitas. Tugas yang diemban seorang indung dalam proses regenerasi manusia menempatkan dalam posisi sentral dalam kehidupan manusia. Peran seperti ini tampaknya "teruraikan" dalam makna upacara-upacara adat tradisional pertanian. Saat panen tiba terdapat upacara nyalin yang menunjukkan aktivitas pemotongan padi sebagai bakal $i b u$ (indung) (Prawira Suganda: 1982: 157-163). $\mathrm{Ibu}$ pare ini merupakan bibit untuk disemaikan kembali pada masa tanam berikutnya. Perlakuan pada Ibu pare sangat istimewa; diawali dari pemotongan hingga penyimpanan ke leuit, lumbung; sarat dengan upacara-upacara khusus. Ibu pare jarang sekali dikonsumsi, fungsinya tidak lain sebagai "penyimpan" benih padi. Dalam rentang sekian bulan bahkan tak jarang ada yang berusia puluhan tahun, $i b u$ pare (indung pare) "disemayankan" di Gedong Ratna Inten (leuit) menunggu untuk disemaikan kembali.

Dalam mitos tradisional budaya Sunda lama (seperti telah diuraikan awal tulisan), mitos perempuan sangat kuat terekat dalam sosok Sunan Ambu. Sosok ini memiliki peran sentral dengan memasuki wilayahwilayah kritis dalam setiap peristiwa kehidupan yang dialami manusia di bumi. Sunan Ambu, menurut Yanti kh (2006) adalah simbol dewi pemelihara, dewi penolong. Ia merupakan simbol spiritualitas tertinggi yang melambangkan Dunia Atas atau langit, sedangkan laki-laki melambangkan Dunia Bawah atau bumi. Peran tokoh Sunan Ambu dalam carita pantun Lutung Kasarung, misalnya, adalah tokoh tertinggi dalam alam kosmos orang Sunda, karena para bujangga yang sakti itu ternyata berada di bawah perintah Sunan Ambu. Begitu juga para Pohaci yang suci berada di bawah perintah Sunan Ambu.

Dugaan masyarakat Sunda lebih condong kepada pemuliaan Indung (baca: perempuan) sudah dirasakan oleh Atmadibrata seorang pakar seni (Mangle No. 1695). Beliau menulis dalam bahasa daerah (Sunda) sebagai berikut:

Dina gending Karesmen kungsi kaebrehkeun Sunan Ambu, nya eta hiji istri pangawasa kahiangan anu dibarengan ku para Pohaci, diantarana Pohaci Girang Candoli anu pancenna ngaruksak tutuwuhan dahareun manusa anu asalna tina waruga Pohaci Sanghyang Sri. Di kahyangan, Sunan Ambu dibarengan oge ku lalaki nu nelah para bujangga, tapi pancenna saukur tukang ancag-incig henteu boga pancen husus.

Dina carita Lutung Kasarung, anu pangreana ngalalakon teh Putri Bungsu Purbasari anu dikakaya ku putri cikal Purbararang. Dina carita Mundinglaya, aya Dewi Asri pasanganana anu ngalambangkeun kasatiaan. Sedengkeun Purbasari mah ngalambangkeun kasabaran jeung katawekalan. Dina carita Sangkuriang, aya Dayang Sumbi ibuna anu awet ngora nepi kadipibogoh ku putrana. Aya keneh wanoja lianna anu penting dina carita Sunda, nyaeta Inten Dewata, dina carita wewengkon Garut. Di Limbangan aya Rambutkasih sarta di Majalengka aya Ambetkasih. Anu gagah mah Nyi Sumur Bandung jeung Rengganis.

Artinya:

Dalam gending karesmen pernah diungkapkan Sunan Ambu, yaitu seorang isteri penguasa kahyangan yang disertai para Pohaci, di antaranya Pohaci Girang Candoli yang bertugas merusak tumbuhan makanan manusia yang berasal dari tubuh Pohaci Sanghyang Sri. Di kahyangan, Sunan Ambu pun disertai laki-laki yang disebut bujangga, tetapi tugasnya hanyalah sebagai 
pesuruh belaka yang tidak mempunyai tugas khusus.

Dalam cerita (pantun) Lutung Kasarung, yang paling banyak diceritakan adalah Putri Bungsu Purbasari yang dianiaya kakak kandungnya sendiri, Purbararang. Pada cerita (pantun) Mundinglaya ada (tokoh) Dewi Asri sebagai pasangannya yang melambangkan kesetiaan. Sedangkan Purbasari melambangkan kesabaran dan ketawekalan. Pada cerita Sangkuriang ada Dayang Sumbi (seorang) ibu yang awet muda hingga dicintai anaknya sendiri. Masih ada tokoh perempuan lain yang penting dalam cerita Sunda adalah Inten Dewata yang berasal dari daerah sekitar Garut. Di (kota) Limbangan ada (tokoh) Rambutkasih serta di Majalengka ada Ambetkasih. Yang gagah adalah Nyi Sumur Bandung (dalam cerita pantun Nyi Sumur Bandung) dan (tokoh) Rengganis (dalam Wawacan Rengganis).

Peranan perempuan dalam arti "pemuliaan" kepada kaum perempuan (indung) lebih kentara pada upacara-upacara yang bertalian dengan adat pertanian. Diawali dengan cerita mitologi Sanghyang Dewi Sri hingga diakhiri dengan berbagai tata laku yang berhubungan dengan perlakuan istimewa pada saat menanam padi. Perilaku hormat kepada Dewi Sri tampak pada awal penanaman hingga pascapanen. Di dalamnya sarat dengan upacara-upacara dan mantra-mantra untuk memulai sebuah pekerjaan. Upacara Seren Taun (1991) oleh masyarakat Kampung Adat Kasepuhan Ciptagelar yang diselenggarakan setiap tahun menunjukkan betapa mendalamnya kecintaan kepada Dewi Sri. Kemudian di daerah Banjaran Kabupaten Bandung sering digelar pula upacara Seleh Taun (2000) yang waktunya digelar setelah panen padi.

Sementara di Urang Kanekes (Baduy), berdasarkan pada catatan pribadi Bapa Surya Saputra (1950: 3-4) yang pernah meneliti perikehidupan Baduy sekitar tahun 50-an menyebutkan adanya kosmologi Sunda yang didasarkan pada peranan perem-puan. Dalam kepercayaan urang Kanekes, ada yang disebut Ambu Langit yaitu perempuan yang akan menugaskan Aing, Aku (aku yang masih dalam kandungan) untuk turun ke alam dunia. Oleh Ambu Langit, si Aing itu diserahkan kepada Ambu Tengah yang bernama Nyi Randakasih. Dari Ambu Tengah kemudian turun lagi ke Ambu Bumi yang bernama Ambu Dayang Wirati. Di sini Si Aing berkenalan dengan Ambu Dayang Wirati dan menerima cinta berahi. Maka dengan perantaraan cinta berahi dan kasih mesra seorang ibu dan seorang ayah yang disebut Indung Simbarang Kandung dan Bapa Simbarang Jadikeun, Si Aing bersemayan di dalam perut Indung Simbarang Kandung. Sesudah sembilan bulan Si Aing berbicara kepada Ambu untuk memohon izin mengembara di Buana Pancatengah.

Di dalam perut Indung Simbarang Kandung yang artinya bunda di dunia, maka Si Aing seolah-olah bertapa untuk melengkapi segala alat tubuh agar dapat menyesuaikan diri dengan keadaan dan isi di Buana Panca Tengah. Cara bertapa Si Aing adalah sebagai berikut:

- Sabulan Ngaherang (Sebulan bening gemilang)

- Dua bulan Ngalenggang (Dua bulan bergerak)

- Tilu bulan Ngarupa (Tilu bulan berupa)

- Opat bulan Ngareka (Empat bulan mereka-bentuk)

- Lima bulan Malik-muter (Lima bulan berbalik-berputar)

- Genep bulan Tumpang pitu (Enam bulan tampang tujuh)

- Tujuh bulan Nunjuk ka Sangiang Manggung(Tujuh bulan menunjuk Sangiang Manggung

- Dalapan bulan Lilimbungan di Tanah Payung (Delapan bulan berlimbung di Tanah Payung

- Salapan bulan Matur ka Ambu rek ngumbara ka buana Panca Tengah (Sembilan bulan pamitan kepada ibu 
hendak mengembara di Buana Pancatengah.

Masih dalam catatan Bapa Surya Saputra (Pa Sursa), dijelaskan adanya adat "beberesih", bersih-bersih pada saat akan dilaksanakan Panen Huma. Beberesih di sini mengandung ati membersihkan lahir dan batin dengan cara berpuasa dan membersihkan badan serta lingkungannya. Pada saat bersih-bersih di lingkungannya terdapat mantra guna menghadirkan para pohaci yang berada di sekitarnya. Berikut adalah mantra yang dimaksud.

\begin{tabular}{|c|c|}
\hline Риииииип & Puuuuuun \\
\hline $\begin{array}{l}\text { Pohaci Haliwungan } \\
\text { jati ngaran imah }\end{array}$ & $\begin{array}{l}\text { Pohaci Haliwungan } \\
\text { jati nama rumah }\end{array}$ \\
\hline $\begin{array}{l}\text { Pohaci Tembragan } \\
\text { jati ngaran golodog }\end{array}$ & $\begin{array}{l}\text { Pohaci Tembragan } \\
\text { jati nama golodog }\end{array}$ \\
\hline $\begin{array}{l}\text { Pohaci Leunjeuran } \\
\text { jati ngaran taraje }\end{array}$ & $\begin{array}{l}\text { Pohaci Leunjeuran } \\
\text { jati nama tangga }\end{array}$ \\
\hline $\begin{array}{l}\text { Pohaci Geblegan } \\
\text { jati ngaran buruan }\end{array}$ & $\begin{array}{l}\text { Pohaci Geblegan jati } \\
\text { nama halaman }\end{array}$ \\
\hline $\begin{array}{l}\text { Pohaci Keliran jati } \\
\text { ngaran sisi buruan }\end{array}$ & $\begin{array}{l}\text { Pohaci Keliran jati } \\
\text { nama sisi halaman }\end{array}$ \\
\hline $\begin{array}{l}\text { Pohaci Rambetan } \\
\text { jati ngaran jalan ka } \\
\text { cai }\end{array}$ & $\begin{array}{l}\text { Pohaci Rambetan jati } \\
\text { nama jalan ka cai }\end{array}$ \\
\hline $\begin{array}{l}\text { Pohaci Keliran jati } \\
\text { ngaran sisi jalan ka } \\
\text { cai }\end{array}$ & $\begin{array}{l}\text { Pohaci Keliran jati } \\
\text { nama sisi jalan ka cai }\end{array}$ \\
\hline $\begin{array}{l}\text { Pohaci Rawengan } \\
\text { jati ngaran areuy }\end{array}$ & $\begin{array}{l}\text { Pohaci Rawengan } \\
\text { jati nama areuy }\end{array}$ \\
\hline $\begin{array}{l}\text { Pohaci Solekat } \\
\text { pandak ngaran } \\
\text { kalakay }\end{array}$ & $\begin{array}{l}\text { Pohaci Solekat } \\
\text { pandak nama } \\
\text { kalakay }\end{array}$ \\
\hline $\begin{array}{l}\text { Pohaci Rambatan } \\
\text { jati ngaran cai }\end{array}$ & $\begin{array}{l}\text { Pohaci Rambatan jati } \\
\text { nama air }\end{array}$ \\
\hline $\begin{array}{l}\text { Pohaci Ureyan jati } \\
\text { ngaran urat cai }\end{array}$ & $\begin{array}{l}\text { Pohaci Ureyan jati } \\
\text { nama urat air }\end{array}$ \\
\hline $\begin{array}{l}\text { Pohaci Leundeuan } \\
\text { jati ngaran leuwi }\end{array}$ & $\begin{array}{l}\text { Pohaci Leundeuan } \\
\text { jati nama lubuk }\end{array}$ \\
\hline $\begin{array}{l}\text { Pohaci Kerepekseah } \\
\text { ngaran curug }\end{array}$ & $\begin{array}{l}\text { Pohaci Kerepekseah } \\
\text { nama curug }\end{array}$ \\
\hline $\begin{array}{l}\text { Pohaci Rencikmanik } \\
\text { ngaran keusik }\end{array}$ & $\begin{array}{l}\text { Pohaci Rencikmanik } \\
\text { nama pasir }\end{array}$ \\
\hline $\begin{array}{l}\text { Pohaci Imbulan jati } \\
\text { ngaran budah }\end{array}$ & $\begin{array}{l}\text { Pohaci Imbulan jati } \\
\text { nama buih }\end{array}$ \\
\hline $\begin{array}{l}\text { Pohaci Tinggulan } \\
\text { jati ngaran batu }\end{array}$ & $\begin{array}{l}\text { Pohaci Tinggulan jati } \\
\text { nama batu }\end{array}$ \\
\hline $\begin{array}{l}\text { Pohaci Balokbokan } \\
\text { jati ngaran sirah cai }\end{array}$ & $\begin{array}{l}\text { Pohaci Balokbokan } \\
\text { jati nama mata air }\end{array}$ \\
\hline $\begin{array}{l}\text { Cicibluk pancuran } \\
\text { emas jolang kancana }\end{array}$ & $\begin{array}{l}\text { Cicibluk pancuran } \\
\text { emas jolang kancana }\end{array}$ \\
\hline $\begin{array}{l}\text { Cicibluk undem } \\
\text { salaka }\end{array}$ & $\begin{array}{l}\text { Cicibluk undem } \\
\text { salaka }\end{array}$ \\
\hline
\end{tabular}

\begin{tabular}{|l|l|}
\hline $\begin{array}{l}\text { Banyu suci badan } \\
\text { suci }\end{array}$ & $\begin{array}{l}\text { Banyu suci badan } \\
\text { suci }\end{array}$ \\
\hline $\begin{array}{l}\text { Beresih badan } \\
\text { awaking }\end{array}$ & Bersih badan aku \\
\hline
\end{tabular}

Indung menjadi sosok sentral spiritual orang Sunda. Kesempurnaan spiritual manusia memunculkan keagungan aspek humanisme sebagai simbol kediriannya. Dalam konteks demikian, pemuliaan atas indung menjadi simbol kesempurnaan bagi pencapaian spiritualitas yang dihayati melalui praktik nilai-nilai kemanusiaan. Indung adalah lambang kehidupan, lambang kesuburan, lambang ketentraman. Hal ini menegaskan pula bahwa puncak spiritualitas itu tidak melulu dicapai melalui pembacaan ayat-ayat Tuhan secara harfiah, melainkan juga dengan penyebaran dan penerapan pesan-pesan ilahiah melalui praktik kemanusiaan seperti seorang indung yang selalu memberikan upaya-upaya terbaiknya bagi terbentuknya insan kamil. Seorang ibu tidak pernah egois atas kepentingannya sendiri. Seorang indung menemukan esensi kebahagian hidupnya melalui kebahagiaan manusia lain. Seorang indung selalu berbagi kehidupan dengan manusia lain.

Dalam konteks ini, seorang ibu atau perempuan diyakini memiliki daya hidup lebih tinggi daripada laki-laki. Di tengah konflik sosial, kemiskinan, dan kesulitan lain dalam menghadapi kelangsungan hidup, tak pelak indung dan anak-anak adalah korban yang paling rentan. Akan tetapi, dalam kondisi demikian, mereka mampu bertahan dan bangkit dari keterpurukan dan ketidakpastian hidup. Naluri alamiah untuk menjaga dan melindungi anak-anak membuat mereka mempu mengalahkan segala sakit dan derita. Sebuah kekuatan spiritual yang diperoleh melalui pengalaman-pengalaman kemanusiaan. Sebuah lagu dalam bentuk Mamaos Sunda berjudul Pupunden Ati, yang ditulis Ny. Saodah Harnadi Natakusumah, (t.th: 18) menguraikan kecintaan dan kasih sayang indung kepada anaknya yang tanpa pamrih.

\section{Pupunden Ati}

(Pujaan Hati) 
Duh anak ibu

Duh anak ibu

nu geulis pupunden ati si cantik pujaan hati

geus bisa ulin

telah bisa main

geus capetang jeung ngopepang berceloteh dan bercengkrama

teu weleh deudeuh tak habis sayang

najan bangor toloheor walau nakal nian

tambah kanyaah tambah sayang

satingkah saparipolah setiap lakunya

Jungjunan ibu

Sanjungan ibu

nu geulis pupunden ati si cantik pujaan hati

duh boga anak duh punya anak

indung wuwuh mikayungyun indung tambah sayang

reup geura kulem tidurlah segera

geus peuting sepi ngajempling malam tlah sepi

diayun-ayun diayun-ayun

barina dihariringan sambil dininabobo

Duh anak ibu

Duh anak ibu

nu geulis pupunden ati si cantik pujaan hati

ibu ngahariring ibu bernyanyi

lain hariring birahi bukan lagu berahi

duh bari tembang duh sambil nembang

lain perbawa asmara

bukan perbawa kasmaran

dieyong-eyong diayun-gendong

lain ngeyong teu sabongbrong bukan asal mengayun
Jungjunan ibu

Sanjungan ibu

nu geulis pupunden ati si cantik pujaan hati

nyaring ku nyaringna khawatir saat jaga

sok inggis ulin teu puguh takut main tak keruan

duh hate indung duh hati indung

salempang pinanggih bahya khawatir beroleh bahaya

indung ngamongmong indung memomong

nyaah suda ti karinah sayang tak terbatas

Pupunden ati

Pujaan hati

najan rungsing matak pusing

walau merengek bakal pusing

da sakapeung mah sebab terkadang

baringsang ngabarungsinang membuat kesal dan mendongkol

mo laas welas tak akan sirna kasih

dirungrum reujeung diambung dirubung dan dicium

bari ngadu'a sambil berdoa

sangkan mulya jeung jatnika. agar mulia dan sejahtera

\section{PENUTUP}

Mitologi perempuan Sunda terdapat pada cerita-cerita pantun, semacam cerita epos (kepahlawanan), dan tradisi-tradisi yang bertalian erat dengan kehidupan pertanian. Ada sejumlah sejumlah nama (tokoh) dalam mitologi Sunda yang diidentifikasikan sebagai tipikal perempuan Sunda, yaitu Dayang Sumbi, Sunan Ambu, dan Nyi Sri Pohaci. Ketiga tipikal tokoh yang berbeda karakter ini diharapkan dapat bersatu, menjelma pada sosok seorang indung, ibu. Indung menjadi lambang spiritual bukan saja untuk perempuan Sunda, tetapi untuk seluruh orang Sunda. Oleh karena dalam diri indung tercermin sifat-sifat teguh pendirian, 
bijaksana, pengayom, dan pendidik. Lebih dari itu semua, indung merupakan kekuatan moral atau kekuatan spiritual, baik untuk diri, keluarga, maupun bangsa.

\section{DAFTAR SUMBER}

\section{Buku}

Atja dan Daleh Danasasmita. 1981. Sanghyang Siksakandang Karesian. Proyek Pengembangan Permuseuman Jawa Barat.

Adimihardja,Kusnaka. 1992.

Kasepuhan yang Tumbuh di atas yang Luruh. Bandung: Tarsito

Bakri, Ahmad. 1976.

Sanghiang Lutung Kasarung.

Jakarta: Pustaka Jaya

Danandjaja, James. 1986.

Foklor Indonesia. Jakarta: Pustaka Grafitipers.

Ekadjati,Edi S. 1983.

'Naskah Sunda: Inventarisasi dan Pencatatan'. Bandung: Lembaga Kebudayaan Unpad - The Toyota Foundation. et.al.1987.

Peta Sejarah Provinsi Jawa Barat. Jakarta: Ditjarahnitra, Depdikbud. 2005.

Kebudayaan Sunda Jilid 1-2. Jakarta: Pustaka Jaya

Emeis,M.G. 1971.

Bunga Rampai Melayu Kuno.

Kualalumpur Malaysia: Dewan

Bahasa dan Pustaka

Harnadi Natakusumah, Saodah.tt.

Tembang Sunda: Sekar Asri.

Hooykay,C. 1952.

Penyedar Sastra. Groningen.

Jakarta: J.B. Wolters.

H.S. Ranggawaluya. 1980.
Regen Boncel. Proyek Penerbitan Buku Sastra Indonesia dan Daerah Depdikbud

Muchtar, R.H. Uton dan Ki Umbara.1977. Modana. Bandung: Mangle Panglipur.

Pamarni. 1980.

Milih Jodo. Proyek Penerbitan

Buku Sastra Indonesia dan Daerah Depdikbud.

Prawira Soeganda, R. Akip. 1982. Upacara Adat Di Pasundan.

Bandung: Sumur Bandung.

Rosidi, Ajip.1985.

Manusia Sunda. Jakarta: Inti Idayu Press.

Salmun, M.A. 1957.

Kandaga Buku Bacaan jilid IV. Bandung: Ganaco.

Sopandi, Atik \& Oyon Sofyan Umsari. 1985.

Kakawihan Barudak Nyanyian anak-anak Sunda. Depdikbud

Dirjen Kebudayaan Proyek Penelitian dan Pengkajian Kebudayaan Nusantara.

Sursa. 1950.

Baduy Naskah 13. Tidak diterbitkan.

Van Peursen,C.A. 1980.

Orientasi di alam filsafat. Jakarta: Gramedia.

2. Makalah

Suryani NS, Elis. 1977. Aspek Mite dalam Carita Pantun. Fakultas Sastra Universitas Pajajaran.

Saputra, Suria (Sursa). 1950. Baduy : Naskah 7, Adat Lembaga. Bogor. 
Otje Djundjunan, Popong. 1997.

Peranan Wanita Sunda Dalam Pembangunan. Bandung: Dirjen Kebudayaan Balai Kajian Sejarah dan Nilai Tradisional.

Dirjen Kebudayaan Balai Kajian Sejarah dan Nilai Tradisional. 1991.

Bandung. Upacara Seren Taun

Kampung Adat Ciptarasa

Kecamatan Cisolok Kabupaten Sukabumi.

Proyek Penelitian Pengkajian dan Pembinaan Nilai-nilai Budaya Jawa Barat. 1992/1993.

Upacara Tradisional Jawa Barat Nadran dan Seren Taun.

Balai Kajian Sejarah dan Nilai Tradisional.
Bandung. 2000.

Upacara Seleh Taun di Kampung adat Cikondang, Desa Lamajang Kecamatan Banjaran Kabupaten Bandung.

\section{Artikel}

Enoch Atmadibrata. Mangle No. 1695.

Kawanitaan Anu Dipuhit ku Ki Sunda.

Cahya Hedy. Pikiran Rakyat: 27 Desember 1999. Seni Tarawangsa di Dalam Mitos

Dewi Sri

Pikiran Rakyat: 6 Juli 2002. Ngalaksa, Upacara Ungkap Rasa Syukur

Neneng Yanti Kh. Pikiran Rakyat: 22

Desember 2006. Sosok Ibu dan Spiritualitas. 